\title{
The Production of Gardenia Reds- The Kinetically Controlled Gardenia Red-1 and the Thermodynamically Controlled Gardenia Red-2
}

\author{
Chiu-Lan Hsieh¹, Wang-Chi Hsieh², Yu-Wen Chen², Charng-Cherng Chyau ${ }^{3}$ and Robert Y Peng ${ }^{3,4 *}$ \\ ${ }^{1}$ Graduate Institute of Biotechnology, Changhua University of Education, Taiwan
}

${ }^{2}$ Day Spring Biotech Co., Ltd., Taiwan

${ }^{3}$ Research Institute of Biotechnology, Hungkuang University, Taiwan

4Research Institute of Medical Sciences, Taipei Medical University, Taiwan

Submission: April 01, 2017; Published: April 28, 2017

"Corresponding author: Robert Y Peng, Research Institute of Biotechnology, Hungkuang University, Research Institute of Medical Sciences, Taipei Medical University, Taiwan, Tel: +886426318652; Email: ypeng@seed.net.tw

\section{Introduction}

Gardenia colors are widely used as food colorants. Gardenia blue (GB) is mainly synthesized via the conjugation reaction of genipin with alpha-amino acids [1] (Figure 1). Previously, we have demonstrated the chemical kinetics of the transformation of geniposide to geniposidic acid [2].

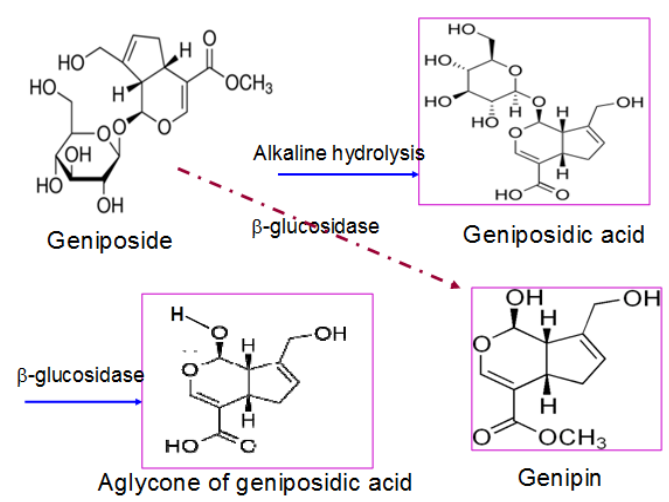

Figure 1: Interconversion of iridoids compounds. A) -glucosidase hydrolyzes geniposide to produce genipin. Through alkaline hydrolysis geniposide is demethylated to produce geniposidic acid, which in turn produces genipin after hydrolyzed by glucosidase.

The production of Gardenia Red (GR) also has been demonstrated by [3] in which geniposidic acid (GPSA) was first deglucosidylated using the enzyme mixture (the main enzyme $\beta$ -glucosidase with activity unit of 45.2Ug-1 was obtained from Aspergillus niger) at $\mathrm{pH} 4.5$ and a temperature $40^{\circ} \mathrm{C}$ to form the alycone of geniposidic acid (AgGNPA), the latter then coupled with different kinds of amino acids to produce Gardenia Reds [3]. Dong synthesized GPSA in alkaline condition (pH 12) [4].
Moritome et al. [5] prepared purified extract from Gardenia fructus which was directly used for synthesis of GR. From our experience, the production of GR is handicapped by a variety factors, like the high content of genipin, the interfering amino acids and proteins.

\section{Materials and Methods}

\section{Chemicals}

Geniposide was purchased from Sigma Aldrich (purity $>98 \%$, St Louis, MO, USA). Other chemicals were provided by Wako Pure Chemicals (Osaka, Japan).

Preparation of GR: The modified method of [5] was followed to prepare GR. The final dextrin addition was omitted. The GR solution was purified by the adsorption macroporous adsorption resin (MinshengTMD101, China) and the desorption of color was eluted by ammonia solution ( $\mathrm{pH} 10.0$ ). The concentrated GR solution was lyophilized.

The powder GR (GR1) was re-dissolved in deionized water to a concentration $0.0001 \mathrm{mg} / \mathrm{mL}$ and the opticall density of which was scanned with Elisa Reader within the range from $480 \mathrm{~nm}$ to $560 \mathrm{~nm}$. The product GR1 was then autoclaved at $121^{\circ} \mathrm{C}$ for 10 min to obtain GR2, which was similarly scanned using the same range of wavelength.

\section{Results and Discussion}

\section{Effect of heating and autoclaving}

GR is thermal stable. The formation of GR1 was facilitated at $90{ }^{\circ} \mathrm{C}$ for $2 \mathrm{~h}$ [5] (Figure 2). GR1 exhibited a maximum absorption at $531 \mathrm{~nm}(\beta m a x=531 \mathrm{~nm})$ with a color value of 2.12. When GR1 was subjected to autoclaving at $121{ }^{\circ} \mathrm{C}$ for $10 \mathrm{~min}$, the ?max 
shifted to $521 \mathrm{~nm}$ (Figure 3), and the same time the color value increased to 3.90 (Figure 2).

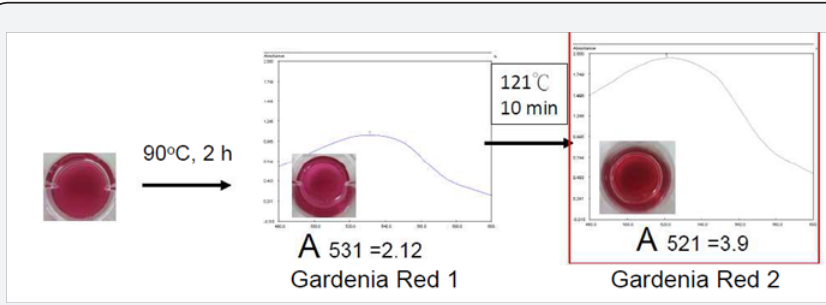

Figure 2: The formation of different Gardenia Red (GR1 and GR2) under different reaction conditions.
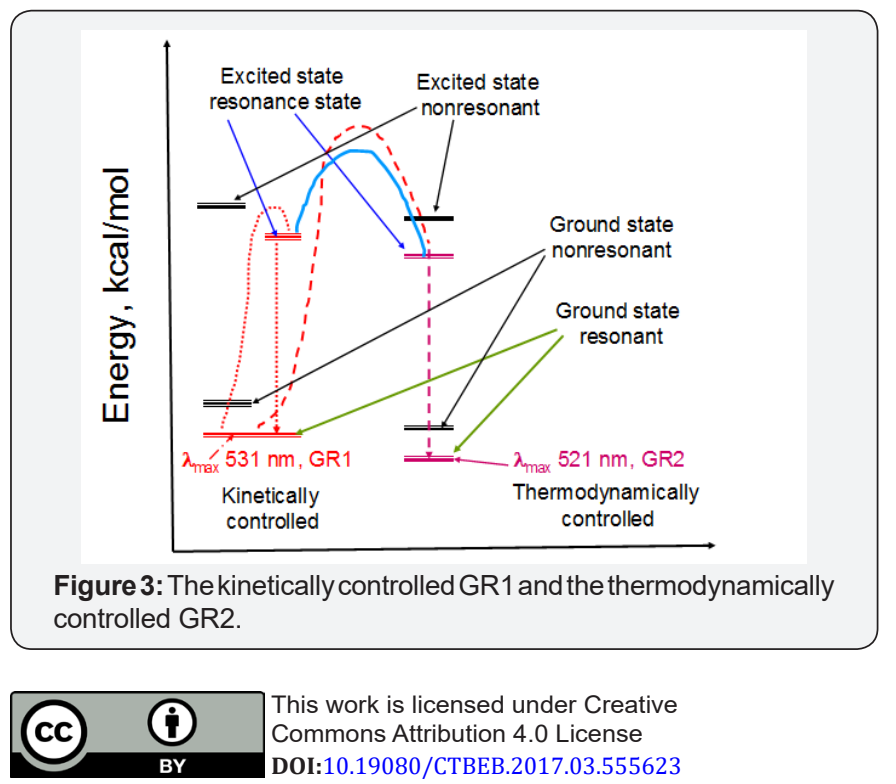

This work is licensed under Creative Commons Attribution 4.0 License

DOI:10.19080/CTBEB.2017.03.555623

\section{Explanation in view of the physico-chemical aspects}

Thus it is likely that GR1 is a product produced by kinetically controlled mechanism, while GR2 is the one called "thermally controlled" product. GR1 showed common red color, while GR2 looked more like a shining rose color (Figure 2 \& 3). To our belief, this is the first time GR has been found to exhibit such an interesting phenomenon involving two different kinetic isomers.

\section{References}

1. Park JE, Lee JY, Kim HG, Hahn TR, Young-Sook Paik YS (2002) Isolation and characterization of water-soluble intermediates of blue pigments transformed from geniposide of Gardenia jasminoides. J Agric Food Chem 50(22): 6511-6514.

2. Xie JH, Liang HZ, Xu YZ, Tang BC (2011) Preparation of gardenia red pigment by hydrolysis of geniposidic acid with co-immobilized enzyme. Advanced Material Research 236(238): 1752-1756.

3. Hsieh CL, Hsieh WC, Lin PX, Peng RY (2015) The inherent reactor kinetics for transformation of geniposidic acid from geniposide in a microreactor. Internl J Eng Res and Appl 5(1)(part 1): 42-65.

4. Dong Z (2007) Preparation and refining of Gardenia Red. China Food Additives 2: 150-153.

5. Moritome N, Kishi Y, Fujii S (1999) Properties of red pigments prepared from geniposidic acid and amino acids. J Sci Food Agric 79: 810-814.

\section{Your next submission with Juniper Publishers will reach you the below assets}

- Quality Editorial service

- Swift Peer Review

- Reprints availability

- E-prints Service

- Manuscript Podcast for convenient understanding

- Global attainment for your research

- Manuscript accessibility in different formats

( Pdf, E-pub, Full Text, Audio)

- Unceasing customer service

Track the below URL for one-step submission https://juniperpublishers.com/online-submission.php 